\title{
CHEMICAL COMPOSITION, ANTIOXIDATIVE AND ANTIMICROBIAL ACTIVITY OF ALLSPICE (PIMENTA DIOICA (L.) MERR.) ESSENTIAL OIL AND EXTRACT
}

Aleksandra Milenković1, Jelena Stanojević ${ }^{1}$, Zorica Stojanović-Radić2 Milica Pejčić², Dragan Cvetković ${ }^{1}$, Jelena Zvezdanović ${ }^{1}$, Ljiljana Stanojević*
(ORIGINAL SCIENTIFIC PAPER) UDC 665.52:582.776.2

\footnotetext{
${ }^{1}$ Faculty of Technology, University of Niš, Leskovac, Serbia

${ }^{2}$ Faculty of Science and Mathematics, University of Niš, Niš, Serbia
}

Allspice (Pimenta dioica (L.) Merr.) fruit was used for the essential oil and ethanolic extract isolation in the present study. The essential oil was obtained by Clevenger-type hydrodistillation from allspice fructus with hydromodule $1: 10 \mathrm{~m} / \mathrm{v}$ during 180 minutes, while the ethanolic extract was obtained by reflux extraction at the boiling temperature with solvomodule $1: 10 \mathrm{~m} / \mathrm{v}$ during 120 minutes. The qualitative and quantitative composition of the essential oil was determined by GC/MS and GC/FID methods, respectively. The total phenolic and total flavonoid content in the extract was determined according to the Folin-Ciocalteu and aluminium chloride methods, respectively The antioxidant activity of allspice fructus essential oil and the extract was determined spectrophotometrically by DPPH assay and the antimicrobial activity using the microdilution method on the following microorganisms: two types of bacteria (Bacillus cereus, Salmonella spp.) and one yeast (Candida albicans), pairs of reference strains and their isolates. The obtained results proved the presence of 20 components in the essential oil, mainly oxygenated monoterpenes. The extract and essential oil have shown the best antioxidant activities after 20 and 60 minutes of incubation with $\mathrm{EC}_{50}$ values of $0.011 \mathrm{mg} / \mathrm{cm}^{3}$ and $0.023 \mathrm{mg} / \mathrm{cm}^{3}$, respectively. Both the essential oil and the extract have shown an inhibitory effect on all investigated microorganisms. Allspice ethanolic extract showed a better inhibitory effect on $B$. cereus and $S$. enterica (isolate and ATCC strains) than the essential oil. On the other side, allspice essential oil showed a better inhibitory effect on $C$. albicans strains. The results obtained indicate that both the essential oil and the extract isolated from allspice fructus are a good source of natural antioxidants and antimicrobial agents with potential applications in food and pharmaceutical industries as a safer alternative to the synthetic additives.
Keywords: Allspice, Essential oil, Extract, Antioxidant activity, Antimicrobial activity

\section{Introduction}

Pimenta is a genus of the flowering plants in the Myrtaceae family, mostly found in the Caribbean region of America, and has about 15 species. Allspice, Pimenta dioica (L.) Merr.) is commonly used for culinary and medicinal purposes, because of the high content of phenolic compounds and various biological activities [1]. Allspice, well known for its fruits called pimento, has been used as an important spice in the food industry, as an ingredient in cosmetic products, as well as a therapeutic agent for diverse diseases. It is also known as allspice due to its intricate aroma which is a medley of aroma from spices such as clove, nutmeg and cinnamon. In India, the leaves of pimenta are used to flavor rice giving it a typical aroma $[2,3]$.

A systematic research of aromatic constituents of allspice' unripe berries and leaves have resulted in a discovery of different metabolites such as phenylpropanoids, galloylglucosides [4], flavonoids and tannins [5], that show numerous (antibacterial, hypotensive, anti-neuralgic and analgesic) properties. Many already known compounds with antioxidant properties are isolated from leaves and berries of allspice, such as quercetin [6], eugenol [7], gallic acid [8] and others. Some studies have shown that eugenol and gallic acid have selective antiproliferative and anti-tumor properties on human cancer cells and their animal models. A compound such as ericifolin from the aqueous extract of allspice berries shows potent anti-prostate cancer and anti-breast cancer properties that could be verified in vitro and in vivo. Considering the phytochemical profile and availability at a low cost of organically-grown berries, allspice may have an additional space in the kitchen and alternative medicine $[9,10]$.

Essential oils are complex mixtures of low molecular weight compounds extracted most commonly by hydrodistillation, than by steam distillation or solvent extraction [11]. The essential oil of allspice can be obtained

\footnotetext{
*Author address: Ljiljana Stanojević, Faculty of Technology, University of Niš,

Bulevar Oslobođenja 124, 16000 Leskovac, Serbia.

E-mail: ljiljas76@yahoo.com; stanojevic@tf.ni.ac.rs

The manuscript received: May,15, 2020.

Paper accepted: June, 18, 2020.
} 
from fructus or leaves with a yield of up to $5 \%$. The major compound of the allspice oil is eugenol (fructus 60-90\%, leaves $>90 \%$ ) [12]. In the essential oils isolated from allspice leaves 1,8-cineole, $\alpha$-humulene, $\beta$-caryophyllene and cadinene-derivatives were found as further important constituents in higher concentrations (up to $10 \%$ for single compounds) in comparison to the oil isolated from fructus [13].

In general, the spices belonging to the Myrtaceae family are rich in polyphenols which are responsible for the antioxidant activity. These secondary metabolites support mainly the natural defense system, depending on the development stage of plants [14].

The first step of this study was the isolation of the essential oil from allspice fructus by Clevenger hydrodistillation and the total extractive matter extraction from the allspice fructus by reflux extraction with $96 \% \mathrm{v} / \mathrm{v}$ ethanol. The second step was to determine the chemical composition of the isolated essential oil and the ethanolic extract, as well as their antioxidant activity using DPPH assay, and the antimicrobial activity using a microdillution method to contribute to a greater use of allspice in pharmaceutical and food industry in southeast Serbia.

\section{Experimental}

\section{Reagents and chemicals}

Ethanol, 96\%, Folin-Ciocalteu reagent, gallic acid, sodium-carbonate $\left(\mathrm{Na}_{2} \mathrm{CO}_{3}\right)$, 1,1-diphenyl-2-picrylhydrazyl (DPPH radical), rutin (Merck, WGK Germany), aluminum(III)-chloride hexahydrate $\left(\mathrm{AlCl}_{3} \cdot 6 \mathrm{H}_{2} \mathrm{O}\right)$, potassium-acetate $\left(\mathrm{CH}_{3} \mathrm{COOK}\right)$, (Sigma Chemical Company, St. Louis, USA), BHT (butylated hydroxytoluene) (Sigma-Aldrich), dimethyl sulfoxide (DMSO). All other chemicals are of analytical grade (p.a.).

\section{Plant material}

The commercial sample of allspice fructus $(P$. dioica (L.) Merr., country of origin: Mexico, packs Gyros Thessaloniki and top spices; Ugrinovski put, part 25-No.32, Zemun, Altina.) was used for investigations. Right before the analysis, the plant material was ground in an electric mill (laboratory electric mill "BRAUN AROMATIC KSM2").

\section{Essential oil isolation}

The essential oil was obtained by Clevenger hydrodistillation, with hydromodule $1: 10 \mathrm{~m} / \mathrm{v}$ for 180 minutes. The isolated oil was separated from the measuring tube after distillation, dried over anhydrous sodium sulfate and stored in the dark vials in a refrigerator at $+4{ }^{\circ} \mathrm{C}$.

Gas chromatography/mass spectrometry (GC/MS) and gas chromatography/flame ionization detection (GC/ FID) analysis of essential oil

GC/MS analysis of the essential oil obtained from allspice fructus was performed on Agilent Technologies 7890 B gas chromatograph, equipped with weakly polar, silica capillary column, HP-5MS (5\% diphenyl- and 95\% dimethyl-polysiloxane, $30 \mathrm{~m} \times 0.25 \mathrm{~mm}, 0.25 \mu \mathrm{m}$ film thickness; Agilent Technologies, Santa Clara, CA, USA) and coupled with inert, selective 5977 A mass detector of the same company. Three $\mu$ of the sample dissolved in diethyl ether in the concentration of 1000 ppm was injected in 5:1 split mode. Helium was used as the carrier gas, at a constant flow rate of $1 \mathrm{ml} / \mathrm{min}$. The oven temperature was programmed from $50{ }^{\circ} \mathrm{C}$ for 2.25 minutes and then increased to $290{ }^{\circ} \mathrm{C}$ at the rate of $4{ }^{\circ} \mathrm{C} / \mathrm{min}$. The temperatures of the MSD transfer line, ion source and quadruple mass analyzer were set at $300{ }^{\circ} \mathrm{C}, 230{ }^{\circ} \mathrm{C}$ and $150{ }^{\circ} \mathrm{C}$, respectively. The ionization voltage was $70 \mathrm{eV}$ and mass range $\mathrm{m} / \mathrm{z}$ 35-650. GC/FID analysis was carried out under identical experimental conditions as GC/MS. The temperature of the FID detector was set at $300{ }^{\circ} \mathrm{C}$. Data processing was performed using MSD Chem-Station, MassHunter Qualitative Analysis and AMDIS_32 softwares (Agilent Technologies, Santa Clara, CA, USA). Retention indices of the components from the analyzed samples were experimentally determined using a homologous series of n-alkanes from $\mathrm{C}_{8}-\mathrm{C}_{20}$ as standards. The percentage composition of a particular component in the essential oil was determined based on the area percent report (uncalibrated calculation procedure) generated by Agilent ChemStation software.

\section{Reflux extraction}

The homogenized plant material $(2.5 \mathrm{~g}$ of ground allspice fructus) was extracted with $96 \%$ ethanol by the reflux extraction for 120 minutes with solvomodule 1:10 $\mathrm{m} / \mathrm{v}$ at the boiling point. After the extraction, the plant material was separated from the liquid extract by vacuum filtration on a Büchner funnel. The solvent was removed by evaporation on a rotary evaporator at $50{ }^{\circ} \mathrm{C}$. The resulting extract was dried in a vacuum oven at $40{ }^{\circ} \mathrm{C}$ to constant weight and stored in the refrigerator at $+4{ }^{\circ} \mathrm{C}$ until analysis. The yield of total extractive matter (TEM, dry extract) was determined by drying the liquid extract in an oven at $105^{\circ} \mathrm{C}$ to constant weight.

Total phenolics content (TPC) in the ethanolic extract

The total phenolics content in the extract was determined spectrophotometrically according to the Folin-Ciocalteu method [15] with certain modifications, using gallic acid as a standard (the concentration range: 0.00625 to $0.2 \mathrm{mg} / \mathrm{cm}^{3}$ ). To $0.5 \mathrm{~cm}^{3}$ of ethanolic extract, $4.5 \mathrm{~cm}^{3}$ of distilled water, $0.5 \mathrm{~cm}^{3}$ Folin-Ciocalteu,s reagent and $5 \mathrm{~cm}^{3}$ of $7 \% \mathrm{Na}_{2} \mathrm{CO}_{3}$ were added. After 90 minutes of incubation at room temperature, the absorbance was determined spectrophotometrically at $765 \mathrm{~nm}$. Total phenolics are expressed as gallic acid equivalents per gram of the dry extract or as gallic acid equivalents per gram of the plant material (mgGAE/g d.e. or mgGAE/g p.m.) according to the Equation 1:

$A_{765 \mathrm{~nm}}=0.01582+5.04832 \cdot \mathrm{cGA}, \mathrm{R}^{2}=0.9991$ 
Total flavonoids content (TFC) in the ethanolic extract

The total flavonoids content was determined according to the aluminum chloride colorimetric method [16-18] with certain modifications, using routine as a standard (the concentration range: 0.005 to $0.100 \mathrm{mg} / \mathrm{cm}^{3}$ ). The reaction mixture was prepared by mixing $2 \mathrm{~cm}^{3}$ of the ethanolic extract with $0.1 \mathrm{~cm}^{3}$ of $10 \% \mathrm{AlCl}_{3} \times 6 \mathrm{H}_{2} \mathrm{O}, 0.1 \mathrm{~cm}^{3}$ of $1 \mathrm{M} \mathrm{CH}_{3} \mathrm{COOK}$ and $2.8 \mathrm{~cm}^{3}$ of distilled water. After 40 minutes of incubation at the room temperature, the absorbance of the reaction mixture was determined spectrophotometrically at $415 \mathrm{~nm}$. The results are expressed as routine equivalents per gram of the dry extract or as routine equivalents per gram of the plant material (mgRE/g d.e. or mgRE/g p.m.) according to the Equation 2 [19]:

$A_{415}=14.171 \cdot C R+4.61 \cdot 10^{-2}, R^{2}=0.9991$

\section{Antioxidant activity (DPPH assay)}

The extract and essential oil of allspice were diluted with ethanol, and a series of solutions of different concentrations were made $\left(0.00732-0.938 \mathrm{mg} / \mathrm{cm}^{3}\right.$ for the essential oil and $0.00197-0.5 \mathrm{mg} / \mathrm{cm}^{3}$ for the extract). The ethanol solution of DPPH radical $\left(1 \mathrm{~cm}^{3}, 3 \times 10-4 \mathrm{~mol} / \mathrm{dm}^{3}\right)$ was added to $2.5 \mathrm{~cm}^{3}$ of the prepared samples. For the extract, the procedure was performed in two samples. For one sample the absorbance at $517 \mathrm{~nm}$ was immediately measured, and another sample was incubated at room temperature and the absorbance was measured after 20 minutes $(A s)$. This procedure was performed in four tests for the essential oil. In one sample the absorbance was immediately measured at $517 \mathrm{~nm}$ and other samples were incubated at room temperature for 20, 40 and 60 minutes in the dark and after that the absorbance was measured $(A s)$. The absorbance at $517 \mathrm{~nm}$ was determined for the ethanolic solution of DPPH radical which was diluted in the same ratio $\left(1 \mathrm{~cm}^{3}\right.$ of the DPPH radical solution with $2.5 \mathrm{~cm}^{3}$ of ethanol, $A_{C}$ ), as well as for the extract or the essential oil before the treatment with DPPH radical $\left(2.5 \mathrm{~cm}^{3}\right.$ of extract/essential oil diluted with $1 \mathrm{~cm}^{3}$ of ethanol, $A_{B}$. Free radical scavenging activity was calculated according to the formula [20]:

DPPH radical scavenging capacity $(\%)=100-\left[\left(A_{s}-A_{B}\right) \cdot \frac{100}{A_{c}}\right] \ldots \ldots$

where $A_{s}$ is the absorbance of the sample, $A_{B}$ is the absorbance of the blank and $A_{C}$ is the absorbance of the control at $517 \mathrm{~nm}$.

DPPH radical scavenging capacity was also determined for butylated hydroxytoluene (BHT). The extract or the essential oil concentration needed for the neutralization of $50 \%$ of the initial DPPH radical concentration is called $\mathrm{EC}_{50}$ value. All experiments were performed in triplicate and the absorbances were measured on Cole Parmer Spectrophotometer.

\section{Antimicrobial activity}

In order to investigate the antimicrobial activity for the obtained essential oil and the extract, the microdilution method was used [21]. The minimum inhibitory concen- tration was determined by the serial dilution method in 96 well microtiter plates. The bacterial strains tested in this method were grown for $18 \mathrm{~h}$ at $37^{\circ} \mathrm{C}$ on Miller Hinton agar (Muller Hinton agar, MHA), while the yeast was grown on Sabouraud Dextrose agar, SDA. The cell suspension was made at sterile Miller Hinton Broth (Muller Hinton Broth, MHB) and Sabouraud Dextrose Broth, SDB. Cell turbidity was adjusted to $0.5 \mathrm{McF}$ arland (turbidity corresponding to the bacterial concentration of 108 cells $/ \mathrm{cm}^{3}$ ) using a densitometer (DEN-1 McFarland Densitometer, Biosan). The final inoculum density was $106 \mathrm{CFU} / \mathrm{cm}^{3}$ (colony forming units). Stocks of the essential oil solutions were made in dimethyl sulfoxide (DMSO) and diluted in sterile MHB. Serial dilutions of the samples (dilution factor $2 \mathrm{x}$ ) were tested, the final concentration range in the medium was $0.02-50 \mathrm{mg} / \mathrm{cm}^{3}$. After the serial dilution of the test oil was prepared, the inoculum was added to the wells and the plates were incubated for $24 \mathrm{~h}$ at $37^{\circ} \mathrm{C}$. The highest solvent concentration of DMSO was $5 \%$ (previously confirmed not to affect cell viability). Antibiotic chloramphenicol for bacteria and antifungal agent nystatin for the yeast were used as a positive control. An uninoculated well with medium without an agent was also left to test its sterility.

The bacterial growth after incubation of the plate was detected by the addition of $20 \mu \mathrm{l}$ of $0.5 \%$ aqueous triphenyltetrazolium chloride (TTC), and the plate was incubated for $30 \mathrm{~min}$. The minimum inhibitory concentration (MIC) was defined as the lowest concentration that inhibits the visible growth (red-colored precipitate at the bottom of the well after the addition of TTC). The minimum microbicidal (bactericidal/fungicidal) concentration (MMK) was defined as the lowest concentration that kills $99.9 \%$ of bacteria/fungi. To determine MMK, $10 \mu \mathrm{l}$ of broth from each well without the visible growth was seeded on nutrient/SDA after which the plates were incubated for $24 \mathrm{~h}$ at $37^{\circ} \mathrm{C}$. All experiments were performed in triplicate.

\section{Results and discussion}

Qualitative and quantitative essential oil composition

Figure 1 shows the influence of hydrodistillation time on the essential oil yield. The maximal essential oil yield of $1.59 \pm 0,01 \mathrm{~cm}^{3} / 100 \mathrm{~g}$ of the plant material was achieved after 180 minutes. Other studies have found similar data for the allspice essential oil yield [7,22,23]. Usually, essential oil percentage yields from allspice are minimalistic, irrespective of the processing technology and the plant part utilized. The yield of the essential oil isolated from fructus is between 1.0 and $4.0 \%[13,24,25]$. The hydrodistillation curve shows that there are two different periods of hydrodistillation (Fig. 1). Namely, in the first hydrodistillation period (the fast oil hydrodistillation) the essential oil was evaporated out from the surface of the plant material cells. In the second, the slow oil hydrodistillation period, a slow molecular diffusion of the essential oil from the internal part of the plant material cells occurred [26]. 


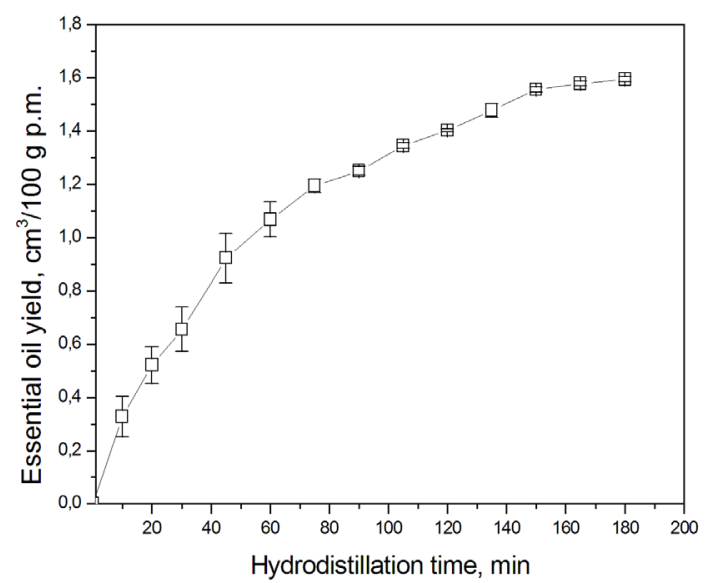

Figure 1. Hydrodistillation kinetics of the allspice essential oil

Components identification in the essential oil was performed by comparing their retention indices (RIexp) with the literary (Rlit) available values; by comparing their mass spectra with the spectra from the Willey, NIST, and RTLPEST libraries (MS) and by co-injecting an identical standard (Co-I) (Table 1) [27]. The percentage content of each component in the essential oil was determined based on the automatic integration of the peak area of the GC/FID signal.

The chemical composition of the allspice essential oil is presented in Table 1, the GC/FID chromatogram is given in Figure 2, and the structures of the major components present in the allspice essential oil are given in Figure 3.

GC/MS analysis of the allspice essential oil resulted in identifying 20 compounds, representing $97 \%$ of the total oil composition (Table 1). The major compounds were eugenol $(48.5 \%)$ and methyl-eugenol $(35.0 \%)$, followed by myrcene $(4.5 \%),(E)$-caryophyllene $(2.5 \%), 1,8$-cineol $(1.8 \%)$, and the others in much smaller percentages. In one study, the chemical composition of the allspice essential oil was analyzed by GC and GC/MS analysis and 45 components were identified, with eugenol $(74.71 \%)$, methyl-eugenol $(4.08 \%)$ and $(E)$-caryophyllene $(4.9 \%)$ being the main components [7]. Dharmadasa and coworkers identified the components in the allspice essential oil by the following order of their abundance: eugenol $(85.33 \pm 2.0 \%)$, $\beta$-caryophyllene $(4.36 \pm 0.3 \%)$, 1,8 -cineole $(4.19 \pm 0.3 \%)$, linalool $(0.83 \pm 0.11 \%)$ and a-humulene $(0.76 \pm 0.12 \%)$ [28]. One review paper reported that this oil contains eugenol (68.6-87.0\%), methyl eugenol (2.9-13.0\%), $\beta$-caryophyllene (2.5-5.4\%) and 1,8 -cineole $(2.3-3.3 \%)$ as main constituents [29]. The high content of eugenol in the essential oil shows a strong antimicrobial activity [30-33]. This phenolic (phenylpropanoid) compound can denature proteins and react with the cell membrane of microorganisms by altering their permeability [34-39]. Regarding the composition of the essential oil of allspice, the pattern that eugenol is present in the highest percentage is usually repeated, followed by methyl-eugenol etc. $[7,13,40]$.

Table 1. Chemical composition of the allspice (P. dioica (L.) Merr.) essential oil

\begin{tabular}{|c|c|c|c|c|c|c|}
\hline No. & $\begin{array}{l}\text { tret, } \\
\min \end{array}$ & Compound & $\mathrm{R}^{\mathrm{exp}^{\mathrm{ex}}}$ & $\mathrm{Rl}^{\text {lit }}$ & $\begin{array}{l}\text { Method of } \\
\text { identification }\end{array}$ & $\begin{array}{l}\text { Content, } \\
\%\end{array}$ \\
\hline 1 & 11.96 & Myrcene & 986 & 988 & RI, MS & 4.5 \\
\hline 2 & 12.45 & a-Phellandrene & 1000 & 1002 & RI, MS & 0.1 \\
\hline 3 & 12.90 & $\alpha$-Terpinene & 1013 & 1014 & RI, MS & $\operatorname{tr}$ \\
\hline 4 & 13.17 & p-Cimene & 1021 & 1020 & RI, MS & 0.2 \\
\hline 5 & 13.33 & Limonene & 1025 & 1024 & RI, MS, Co-I & 0.4 \\
\hline 6 & 13.42 & 1,8-Cineole & 1028 & 1026 & RI, MS, Co-I & 1.8 \\
\hline 7 & 14.02 & $(E)$ - $\beta$-Ocimene & 1044 & 1044 & RI, MS & 0.4 \\
\hline 8 & 14.42 & $y$-Terpinene & 1056 & 1054 & RI, MS, Co-I & 0.1 \\
\hline 9 & 18.69 & Terpinen-4-ol & 1176 & 1174 & RI, MS & 0.5 \\
\hline 10 & 19.15 & $\alpha$-Terpineol & 1189 & 1186 & RI, MS, Co-I & 1.4 \\
\hline 11 & 19.40 & Methyl chavicol & 1196 & 1195 & RI, MS, Co-I & 0.1 \\
\hline 12 & 24.95 & Eugenol & 1363 & 1356 & RI, MS, Co-I & 48.5 \\
\hline 13 & 25.44 & $\alpha$-Copaene & 1378 & 1374 & RI, MS & 0.1 \\
\hline 14 & 25.92 & $\beta$-Elemene & 1393 & 1389 & RI, MS & 0.3 \\
\hline 15 & 26.37 & Methyl eugenol & 1407 & 1403 & RI, MS & 35.0 \\
\hline 16 & 26.86 & $(E)$-Caryophyllene & 1423 & 1417 & RI, MS & 2.5 \\
\hline 17 & 27.90 & $\alpha-$ Humulene & 1457 & 1452 & RI, MS & 0.4 \\
\hline 18 & 29.14 & $\alpha$-Selinene & 1498 & 1498 & RI, MS & 0.2 \\
\hline 19 & 29.81 & Myristicine & 1521 & 1517 & RI, MS & 0.3 \\
\hline 20 & 29.91 & $\delta$-Cadinene & 1525 & 1522 & RI, MS & 0.2 \\
\hline & & & \multicolumn{3}{|c|}{ Total identified (\%) } & 97.0 \\
\hline
\end{tabular}

Grouped components (\%)

Monoterpene hydrocarbons (1- 5.7

$5,7,8)$

Oxygen-containing

monoterpenes $(6,9-12,15,19) \quad 87.6$

Sesquiterpene hydrocarbons 3.7

$(13,14,16-18,20)$

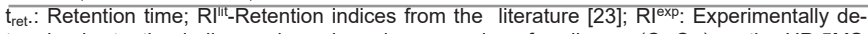
termined retention indices using a homologous series of n-alkanes $\left(C_{8}-C_{20}\right)$ on the HP-5MS column. MS: constituent identified by mass-spectra comparison; RI: constituent identified by retention index matching; Co-l: constituent identity confirmed by GC co-injection of an authenretention index matching; Co-l: constituent
tic sample; $\mathrm{tr}=$ trace amount $(<0.05 \%)$.

The yield of total extractive matter

The yield of total extractive matter (TEM) isolated from the allspice fructus during the reflux extraction process (solvomodule 1:10 m/v, extraction time $120 \mathrm{~min}$ ) was $6.99 \pm 0.09 \mathrm{~g} / 100 \mathrm{~g} \mathrm{p} . \mathrm{m}$.

The yield of the extractive matter depends on the solvomodule, the extraction time, the solvent (solvency), the quality of the plant material itself and the chemical composition of the plant material used [41-43]. The yield of TEM from allspice, obtained by the extraction with ethanol as a solvent using a solvomodule of $1: 10 \mathrm{~m} / \mathrm{v}$ is up to $7 \%$ according to current literature data [44], which agrees with the results obtained in this paper.

Total phenolics and total flavonoids content (TPC and TFC) in the ethanolic allspice extract

The content of total phenolics and total flavonoids in the allspice ethanolic extract was determined based on the calibration curve equations (Equations 1 and 2, Experimental Section). The results were expressed per 
gram of the dry extract (d.e.). The amount of total phenolic and total flavonoid compounds were $273.29 \pm 0.68 \mathrm{mg}$ GAE/g d.e. and $22.21 \pm 0.24 \mathrm{mg} \mathrm{RE} / \mathrm{g}$ d.e., respectively. According to recent research, methanolic and aqueous extracts of allspice fruit are also a significant source of phenols and flavonoids. The total phenolic content in both methanol and water extracts of allspice fruit were $728.4 \pm 137.5 \mathrm{GAE} / \mathrm{g}$ and $678.3 \pm 141.1 \mathrm{GAE} / \mathrm{g}$. The total flavonoid content in methanol and water extracts were $595.31 \pm 51.77 \mathrm{mgCE} / 100 \mathrm{~g}$ and $255.99 \pm 9.89$ $\mathrm{mgCE} / 100 \mathrm{~g}$ (mg catechin equivalents/100g) [45].

The phenol composition in plants depends on many factors such as variety, genotype, climatic conditions, raw material sweetening, processing and various treatments of the plant material [46]. Even earlier, phenolic compounds have been associated with the antioxidant activity and played an important role in stabilizing lipid peroxidation [47].

Polar solvents frequently used for extracting polyphenols include ethanol, ethyl acetate, methanol and acetone [48]. Acetone is better suited for extracting flavonoids, and methanol for extracting polyphenols [49]. These solvents can also be combined to provide better extraction of phenolic compounds [40]. Methanol can extract more polyphenols from the sample compared to the water extraction method $[50,51]$. Ethanol and methanol could be used for the extraction of these compounds, with ethanol being selected for extraction in this work because of its less toxicity $[52,53]$.

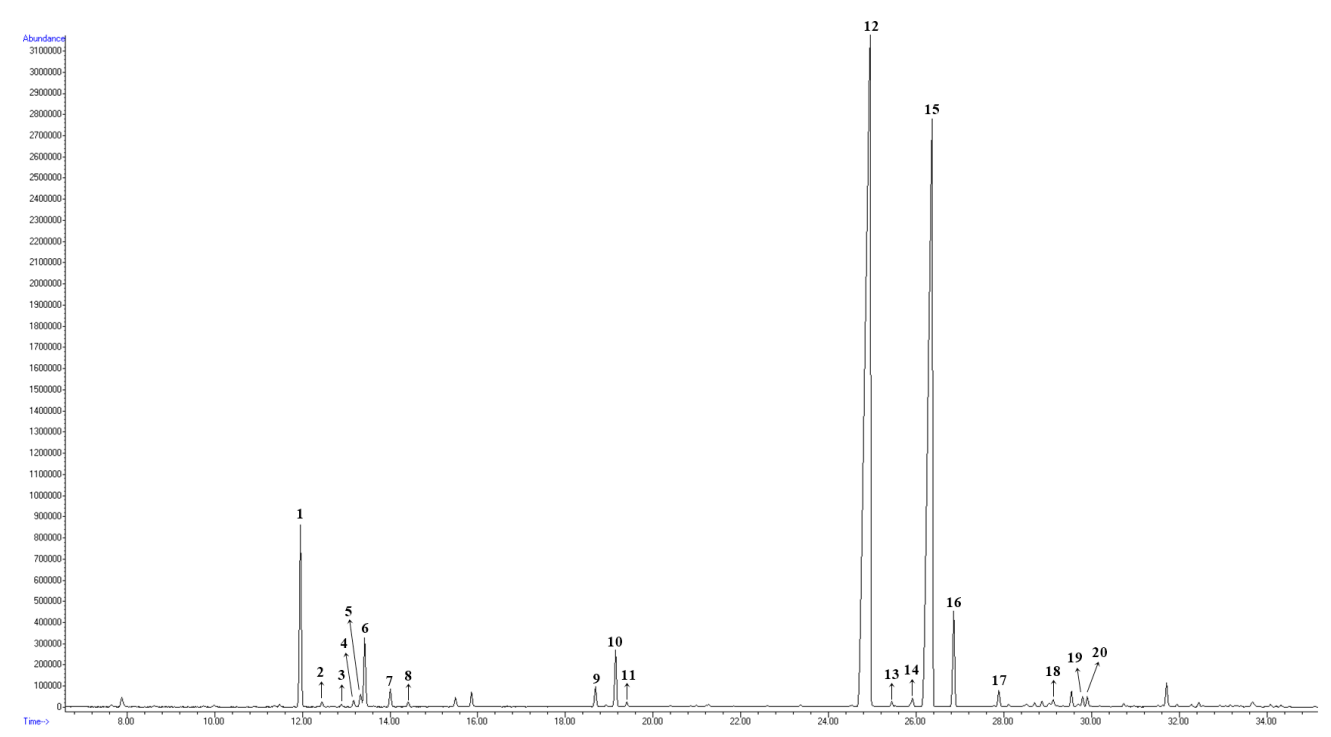

Figure 2. GC/FID chromatogram of the allspice (Pimenta dioica (L.) Merr.) essential oil<smiles>C=CCc1ccc(O)c(OC)c1</smiles>

Eugenol<smiles>C=CCc1ccc(OC)c(OC)c1</smiles>

Methyl eugenol

Figure 3. Structures of the major components identified in the allspice essential

Antioxidant activity of essential oil and extract

The antioxidant activity of the obtained essential oil and extract was studied using DPPH assay. DPPH radical absorbs at $517 \mathrm{~nm}$ (violet in color). When exposing the radical to free radical scavengers, its absorbance significantly decreases because of the hydrogen atom transfer from antioxidant to radical. Thereby, the absorb- ance decrease indicates the antioxidant potential of the studied sample [54].

Based on the absorbance values obtained (control, sample and blank), the degree of neutralization of DPPH radical (\%) by the samples analyzed was calculated. It increases with the increase of the essential oil or the extract concentration being the lowest for no incubated 
samples (Figures 4 and 5).

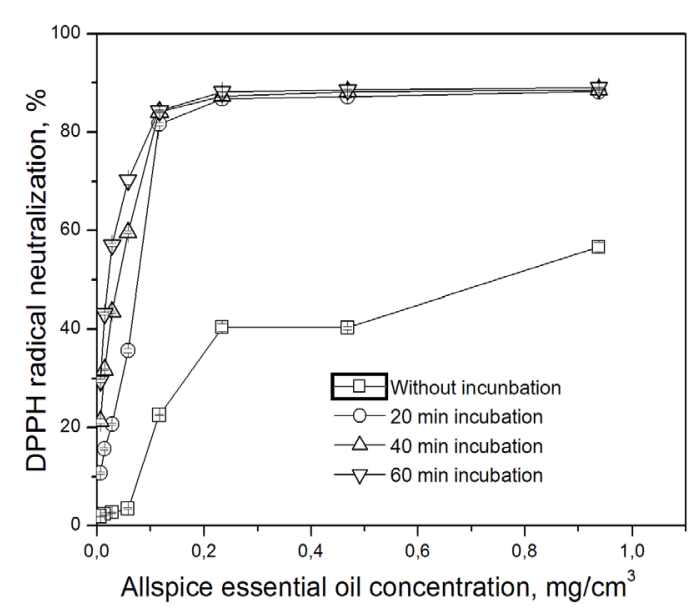

Figure 4. Antioxidant activity of the allspice essential oil

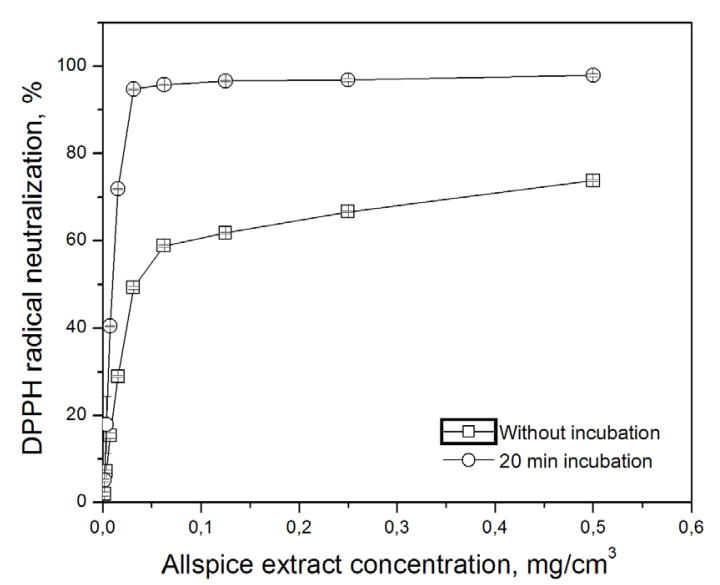

Figure 5. Antioxidant activity of the allspice ethanolic extract

$\mathrm{EC}_{50}$ values for allspice essential oil were: 0.194 , $0.066,0.037,0.023 \mathrm{mg} / \mathrm{cm}^{3}$, without incubation, with 20 , 40 and 60 min incubation, respectively. $E_{50}$ values for allspice ethanolic extract were: 0.060 and $0.011 \mathrm{mg} / \mathrm{cm}^{3}$, without incubation and with 20 minutes incubation, respectively. The extract and the essential oil showed a good, concentration-dependent antioxidant activity (Figures 4 and 5 ).

Based on the $\mathrm{EC}_{50}$ values obtained, the extract showed a better antioxidant activity (lower $\mathrm{EC}_{50}$ values) than the essential oil comparing the values without incubation $\left(0.060\right.$ vs. $\left.0.194 \mathrm{mg} / \mathrm{cm}^{3}\right)$ and after 20 minutes of incubation $\left(0.011 \mathrm{vs} .0 .066 \mathrm{mg} / \mathrm{cm}^{3}\right)$ with radical. This behavior of the extract is probably due to the synergistic action of phenolic compounds, especially flavonoids present therein. There are a large number of scientific papers in which the antioxidant activity of phenols and flavonoids has been confirmed $[50,55,56]$. Phenols and flavonoids are very important plant ingredients. The highly significant correlations obtained in different studies
[57-59] support the hypothesis that phenolic compounds significantly contribute to the total antioxidant capacity of the plants species, due to their ability to "scavenge" free radicals. This is in accordance with the findings of Cai et al. and Djeridane et al. who found a linear correlation between the content of total phenolic compounds and the antioxidant capacity of several plant species [60,61]. Phenolic compounds are effective donors of hydrogen atoms, which make them very good antioxidants [62]. A good antioxidant activity of the essential oil probably comes from the most abundant components, eugenol and methyl-eugenol $[63,64]$.

The results obtained in our study are in agreement with previous studies [28], which reported that the allspice essential oil contains eugenol, methyl eugenol and caryophyllene as its main components. Eugenol is a natural compound present in many aromatic herbs, spices and foods, and is used in cosmetics and pharmaceuticals. Eugenol has a dual effect on oxidative stress, it can act both as an antioxidant or a prooxidant. Also, it exhibits anticancer, cytotoxic, and antitumor activity [65].

The allspice ethanolic extract has shown a better antioxidant activity than the synthetic antioxidant $\mathrm{BHT}\left(\mathrm{EC}_{50}\right.$ value measured after $20 \mathrm{~min}$ of incubation: $0.011 \mathrm{mg} / \mathrm{cm}^{3}$ for the allspice ethanolic extract vs. $0.021 \mathrm{mg} / \mathrm{cm}^{3}$ for BHT. The essential oil exhibited a slightly lower antioxidant activity compared to BHT, but only after 60 min of incubation. Considering that $\mathrm{BHT}$ is one of the most commonly used antioxidants, but with harmful effects on the organism [66], it could be concluded that the tested allspice essential oil and the extract, especially the extract, represent an alternative to this antioxidant with potential application in pharmaceutical and food products.

\section{Antimicrobial activity}

The antimicrobial activity of the obtained essential oil and the extract was determined by the microdilution method [21]. Minimum inhibitory (MIC) and minimum microbicidal concentration (MMC) were determined for all samples. The results of these tests are shown in Tables 2 and 3 , respectively.

Table 2. Determination of MIC values for the allspice essential oil and the extract

\begin{tabular}{|c|c|c|c|c|}
\hline \multirow[b]{2}{*}{ Microorganism } & \multirow[b]{2}{*}{ Source of strain } & \multicolumn{3}{|c|}{ MIC $\left(\mathrm{mg} / \mathrm{cm}^{3}\right)$} \\
\hline & & I & II & $\begin{array}{l}\text { Antibioticl } \\
\text { antimycotic }\end{array}$ \\
\hline Bacillus cereus & Isolate from food & 3.12 & 1.56 & 0.001 \\
\hline Bacillus cereus & ATCC 11778 & 3.12 & 1.56 & 0.0008 \\
\hline Candida albicans & Isolate (feces) & 1.56 & 3.12 & 0.004 \\
\hline Candida albicans & ATCC 24433 & 1.56 & 6.25 & 0.004 \\
\hline Salmonella spp. & Isolate (feces) & 6.25 & 0.39 & 0.006 \\
\hline \multicolumn{5}{|l|}{ Salmonella enterica } \\
\hline ssp. enterica & ATCC 13078 & 3.12 & 1.56 & 0.003 \\
\hline
\end{tabular}

I-allspice essential oil; Il-allspice ethanolic extract 
Table 3. Determination of MMC values for allspice the essential oil and the extract

\begin{tabular}{cccc}
\hline Microorganism & Source of strain & MMC $\left(\mathbf{m g} / \mathbf{c m}^{3}\right)$ \\
& & I & II \\
\hline Bacillus cereus & Isolate from food & I & 12.5 \\
Bacillus cereus & ATCC 11778 & / & 50 \\
Candida albicans & Isolate (feces) & 3.1 & 6.25 \\
Candida albicans & ATCC 24433 & 6.25 & 12.5 \\
Salmonella spp. & Isolate (feces) & 25 & 50 \\
Salmonella enterica & & & \\
ssp. enterica & ATCC 13078 & 6.25 & 12.5 \\
\hline
\end{tabular}

I-allspice essential oil; II-allspice ethanolic extract

Antimicrobial testing was performed against two types of bacteria (Bacillus cereus and Salmonella enterica) and one yeast (Candida albicans), which are potential intestinal pathogenic microorganisms, with pairs of reference strains and their isolates. The essential oil and the extract obtained from allspice were tested in the concentration range of $0.02-50.0 \mathrm{mg} / \mathrm{cm}^{3}$.

The allspice essential oil and the extract have shown an inhibitory effect on all microorganisms. Among the tested samples, the extract exhibited an inhibitory effect at significantly lower concentrations than the essential oil on Bacillus and Salmonela (isolates and ATCC strains) while the essential oil showed a better inhibitory effect on C. albicans (Table 2).

Knowing that Bacillus species often cause alimentary toxic infections in humans, they can cause a variety of other diseases: septic meningitis, cellulitis, gangrene, and numerous eye infections [67], these results can be of great importance.

The allspice ethanolic extract has shown a microbicidal effect on all microorganisms, while the obtained essential oil did not affect only $B$. cereus strains (Table 3 ).

The antimicrobial activity of the extract and the essential oil from allspice has been reported in the literature [68-70] with the emphasis placed on pathogenic bacterial strains. Spices are the most widely used natural antimicrobials in foods being used for thousands of years in food preservation, and as additives to enhance aroma and taste [71]. Phytocompounds which have good solubility in ethanol include tannins, polyphenols, polyacetylene, flavonoids, sterols and alkaloids [72]. The fungicidal action of ethanolic extracts of herbs leads to lysis of the cell wall or cytoplasmic membrane of fungi and the release of antimicrobial substances directly into the cytoplasm [73].

Allspice is rich in glycosides and polyphenols that exhibit antibacterial, fungicidal and antiviral properties $[9,74,75]$. According to all the literature data available for the antimicrobial activity of allspice essential oil, it was concluded that compounds such as eugenol, methyleugenol, $(E)$-caryophyllene, terpinen-4-ol and o-cymene are responsible for this activity [76-79].

\section{Conclusion}

The presented results indicate that the allspice essential oil and the ethanolic extract could be used as a potential source of natural antioxidants and antimicrobial agents for the food, pharmaceutical and chemical industry. Therefore, these isolates from allspice fructus represent the alternative to synthetic additives that could be toxic and carcinogenic. So, it is interesting to investigate its application as natural additives in some final food and pharmaceutical products, for preservation and/or extension of shelf life of raw and processed foods, as well as pharmaceuticals. Besides, the presented results suggested that use of allspice is not just reasonable, but it should be even favored in the traditional Serbian cuisine.

\section{Acknowledgments}

This work was supported by the Ministry of Education, Science and Technological Development of the Republic of Serbia under the Program of financing scientific research work, number 451-03-68/2020-14/200133 (Project assigned to the Faculty of Technology, Leskovac, University of Niš, researchers' group, TR 34012).

\section{References}

[1] C. Chaverri, J. F. Cicció, Leaf and fruit essential oil compositions of Pimenta guatemalensis (Myrtaceae) from Costa Rica, Revista de biologia tropical, 63(1) (2015) 303311.

[2] P. S. Rao, S. Navinchandra, K. N. Jayaveera, An important spice, Pimenta dioica (Linn.) Merill: A review, International Current Pharmaceutical Journal, 1(8) (2012) 221-225.

[3] C.Dima, M. Cotârlet, P. Alexe, S. Dima, Microencapsulation of essential oil of pimento (Pimenta dioica (L) Merr.) by chitosan/k-carrageenan complex coacervation method, Innovative Food Science \& Emerging Technologies 22, (2014) 203-211.

[4] H. Kikuzaki, S. Hara, Y. Kawai, N. Nakatani, Antioxidative phenylpropanoids from berries of Pimenta dioica, Phytochemistry, 52(7) (1999) 1307-1312.

[5] M. S. Marzouk, F. A. Moharram, M. A. Mohamed, A. M Gamal-Eldeen, E. A. Aboutabl, Anticancer and antioxidant tannins from Pimenta dioica leaves, Zeitschrift für Naturforschung C, 62(7-8) (2007) 526-536.

[6] Y. Miyajima H. Kikuzaki, M. Hisamoto, N. Nikatani, Antioxidative polyphenols from berries of Pimenta dioica, Biofactors, 22(1-4) (2004) 301-303.

[7] K. P. Padmakumari, I. Sasidharan, M. M. Sreekumar, Composition and antioxidant activity of essential oil of pimento (Pimenta dioica (L) Merr.) from Jamaica, Natural Product Research, 25(2) (2011) 152-160.

[8] H. Kikuzaki, A. Sato, Y. Mayahara, N. Nakatani, Galloylglucosides from berries of Pimenta dioica, Journal of Natural Products, 63(6) (2000) 749-752.

[9] L. Zhang, B. Lokeshwar, Medicinal properties of the Jamaican pepper plant Pimenta dioica and Allspice, Current Drug Targets, 13(14) (2012) 1900-1906.

[10] P. C. R. K. Tenne, M. M. S. C. Karunaratne, Phytochemical profile and bioactivity of essential oil from Pimenta dioica 
leaves on cowpea beetle, Callosobruchus maculatus (F.) (Coleoptera: Bruchidae): A farmer friendly solution for postharvest pest management, Open Agriculture, 3(1), (2018) 301-309.

[11] T. Nakatsu, A. T. Lupo Jr, J. W. Chinn Jr, R. K. Kang, Biological activity of essential oils and their constituents, Studies in Natural Products Chemistry, 21 (2000) 571-631.

[12] G. P. Kamatou, I. Vermaak, A. M. Viljoen, Eugenol-from the remote Maluku Islands to the international market place: a review of a remarkable and versatile molecule, Molecules, 17(6) (2012) 6953-6981.

[13] L. Jirovetz, G. Buchbauer, I. Stoilova, A. Krastanov, A. Stoyanova, E. Schmidt, Spice plants: Chemical composition and antioxidant properties of Pimenta Lindl. essential oils, part 1: Pimenta dioica (L.) Merr. leaf oil from Jamaica, Nutrition-Vienna, 31(2) (2007) 55.

[14] K. N. Chidambara Murthy, M. Shivapriya, P. Monika, B. Tejashree, Challenges in optimal utilization of bioactive molecules clinically, Bioactive Molecules in Food, (2018) 109-136.

[15] V. L. Singleton, J. A. Rossi, Colorimetry of total phenolics with phosphomolybdic-phosphotungstic acid reagents, American journal of Enology and Viticulture, 16(3) (1965) 144-158.

[16] C. C. Chang, M. H. Yang, H. M. Wen, J. C. Chern, Estimation of total flavonoid content in propolis by two complementary colorimetric methods, Journal of Food and Drug Analysis, 10(3) (2002) 178-182.

[17] J. Y. Lin, C. Y. Tang, Determination of total phenolic and flavonoid contents in selected fruits and vegetables, as well as their stimulatory effects on mouse splenocyte proliferation, Food Chemistry, 101(1) (2007) 140-147.

[18] G. N. Sharma, S. K. Dubey, N. Sati, J. Sanadya, Antiinflammatory activity and total flavonoid content of Aegle marmelos seeds, International Journal of Pharmaceutical Sciences and Drug Research, 3(3) (2011) 214-218.

[19] Lj. Stanojević, M. Stanković, V. Nikolić, Lj. Nikolić, D. Ristić, J. Čanadanovic-Brunet, V. Tumbas, Antioxidant activity and total phenolic and flavonoid contents of Hieracium pilosella L. extracts, Sensors, 9(7) (2009) 5702-5714.

[20] J. S. Stanojević, Lj. P. Stanojević, D. J. Cvetković, B. R. Danilović, Chemical composition, antioxidant and antimicrobial activity of the turmeric essential oil (Curcuma longa L.), Advanced technologies, 4(1) (2015) 07-15.

[21] M. S. Stanković, Z. S. Radić, J. Blanco-Salas, F. M. Vázquez-Pardo, T. Ruiz-Téllez, Screening of selected species from Spanish flora as a source of bioactive substances, Industrial Crops and Products, 95 (2017), 493-501.

[22] A. O. Tucker, J. Maciarello, L. R. Landrum, Volatile leaf oils of caribbean Myrtaceae. II. Pimenta dioica (L.) Merr. of Jamaica, Journal of Essential Oil Research, 3(3) (1991) 195-196.

[23] B. Marongiu, A. Piras, S. Porcedda, R. Casu, P. Pierucci, Comparative analysis of supercritical $\mathrm{CO}_{2}$ extract and oil of Pimenta dioica leaves, Journal of Essential Oil Research, 17(5) (2005) 530-532.

[24] P. Weyerstahl, H. M. Weyerstahl, C. Christiansen, B. O. Oguntimein, A. O. Adeoye, Volatile constituents of Eugenia uniflora leaf oil, Planta Medica 54(06) (1988) 546-549.

[25] M. Yoshimura, Y. Amakura, T. Yoshida, Polyphenolic compounds in clove and pimento and their antioxidative activities, Bioscience, Biotechnology, and Biochemistry
Journal, 75(11) (2011) 2207-2212.

[26] Lj. P. Stanojević, J. S. Stanojević, D. J. Cvetković, D. P. Ilić, Antioxidant activity of oregano essential oil (Origanum vulgare L.), Biologica Nyssana, 7(2) (2016) 133-135.

[27] R. P. Adams, Identification of essential oil components by gass chromatography/mass spectrometry, $4^{\text {th }}$ Ed. Allured Publishing Corporation, Illinois 2007.

[28] R. M. Dharmadasa, D. C. Abeysinghe, D. M. N. Dissanayake, K. W. Abeywardhane, N. S. Fernando, Leaf essential oil composition, antioxidant activity, total phenolic content and total flavonoid content of Pimenta dioica (L.) Merr (Myrtaceae): A superior quality spice grown in Sri Lanka, Universal Journal of Agricultural Research, 3(2) (2015) 49-52.

[29] J. A. P. Alea, Los componentes volátiles de las especias. $X$. Pimiento, Alimentaria: Revista de tecnología e higiene de los alimentos, 301 (1999) 87-90.

[30] S. K. Rao, M. A. Iyengar, G. Rao, Anti-microbial activity of the essential oil of the leaves of Pimenta dioica, Linn (Family: Myrtaceae), Indian Drugs, 38(9) (2001) 458-461.

[31] M. Oussualah, S. Caillet, L. Saucier, M. Lacroix, Antimicrobial effects of selected plant essential oils on the growth of Pseudomonas putida strain isolated from meat, Meat Science, 73(2) (2006) 236-244

[32] O. S. Monteiro, A. G. Souza, L. E. B. Soledade, N. Queiroz, A. L. Souza, V. E. Mouchrek Filho, A. F. F. Vasconcelos, Chemical evaluation and thermal analysis of the essential oil from the fruits of the vegetable species Pimenta dioica Lindl, Journal of Thermal Analysis and Calorimetry, 106(2), (2011) 595-600.

[33] R. P. Fernandes, Caracterização química, avaliação da toxicidade e atividade moluscicida dos óleos essenciais da folha de Pimenta dióica Lindl, casca de Citrus limon Linneo e Rizoma de Zingiber officinale Roscoe, Tese (Doutorado), Universidade federal da Paraiba, 2011.

[34] J. Sikkema, J. A. de Bont, B. Poolman, Interactions of cyclic hydrocarbons with biological membranes, Journal of Biological Chemistry, 269(11) (1994) 8022-8028.

[35] A. Ultee, E. P. W. Kets, E. J. Smid, Mechanisms of action of carvacrol on the food-borne pathogen Bacillus cereus, Applied and Environmental Microbiology, 65(10) (1999) 4606-4610.

[36] S. G. Griffin, S. G. Wyllie, J. L. Markham, D. N. Leach, The role of structure and molecular properties of terpenoids in determining their antimicrobial activity, Flavour and Fragrance Journal, 14(5) (1999) 322-332.

[37] A. S. Naidu, Phyto-phenols, Natural Food Antimicrobial Systems, CRC Press, Boca Raton, FL, 2000, pp. 265-293.

[38] H. J. D. Dorman, S. G. Deans, Antimicrobial agents from plants: antibacterial activity of plant volatile oils, Journal of Applied Microbiology, 88(2) (2000) 308-316.

[39] Y. Y. Andrade-Avila, J. Cruz-Olivares, C. Pérez-Alonso, C. H. Ortiz-Estrada, M. D. C. Chaparro-Mercado, Supercritical extraction process of allspice essential oil, Journal of Chemistry, 2017 (2017) 1-2.

[40] M. Zabka, R. Pavela, L. Slezakova, Antifungal effect of Pimenta dioica essential oil against dangerous pathogenic and toxinogenic fungi, Industrial Crops and Products, 30(2) (2009) 250-253.

[41] S. Milošević, Extraction of Ginkgo biloba L. by carbon (IV)oxide under pressure, Doctoral dissertation, University of Novi Sad, Faculty of Technology, 2011.

[42] Lj. P. Stanojević, M. Z. Stanković, M. D. Cakić, V. D. Nikolić, Lj. B. Nikolić, D. P. Ilić, The effect of the operation 
conditions and the extraction techniques on the yield, kinetics and the composition of the methanol extracts of Hieracium pilosella L., Hemijska Industrija, 63(2) (2009) 79-86.

[43] Lj. Stanojević, B. Stanković, M. Cakić, V. Nikolić, D. Ilić, M. Perić, The influence of extraction techniques on the yield, kinetics and composition of aqueous extracts from dill fruit (Anethi fructus), Savremene tehnologije, 3(1) (2014) 2329.

[44] T. M. A. Stewart, H. I. Lowe, C. T. Watson, Quantification and characterization of Pimenta dioica (Allspice) essential oil extracted via hydrodistillation, solvent and super critical fluid extraction methodologies, American Journal of Essential Oils and Natural Products, 4(3) (2016) 27-30.

[45] E. N. Onwasigwe, Antioxidant and anticarcinogenic effects of allspice, Doctoral dissertation, Alabama Agricultural and Mechanical University, 2017.

[46] F. Martinelli, B. Basile, G. Morelli, R. d'Andria, P. Tonutti, Effects of irrigation on fruit ripening behavior and metabolic changes in olive, Scientia Horticulturae, 144 (2012) 201-207.

[47] G. C. Yen, P. D. Duh, C. L. Tsai, Relationship between antioxidant activity and maturity of peanut hulls, Journal of Agricultural and Food Chemistry, 41(1) (1993) 67-70.

[48] H. Wang, K. Helliwell, Determination of flavonols in green and black tea leaves and green tea infusions by high-performance liquid chromatography, Food Research International, 34(2-3) (2001) 223-227.

[49] O. H. Lowry, N. J. Rosebrough, A. L. Farr, R. J. Randal, Protein measurement with the folin phenol reagent, Journal of Biological Chemistry, 193(1) (1951) 265- 275.

[50] E. Schmidt, L. Jirovetz, K. Wlcek, G. Buchbauer, V. Gochev, T. Girova, A. Stoyanova, M. Geissler, Antifungal activity of eugenol and various eugenol-containing essential oils against 38 clinical isolates of Candida albicans, Journal of Essential Oil Bearing Plants, 10(5) (2007) 421-429.

[51] P. B. C. Panawala, D. C. Abeysinghe, R. M. Dharmadasa, Phytochemical distribution and bioactivity of different parts and leaf positions of Pimenta dioica (L.) Merr (Myrtaceae), World, 4(5) (2016) 143-146.

[52] J. Dai, R. J. Mumper, Plant phenolics: extraction, analysis and their antioxidant and anticancer properties, Molecules, 15(10) (2010) 7313-7352.

[53] A. Suárez, G. Ulate, J. F. Ciccio, Cardiovascular effects of ethanolic and aqueous extracts of Pimenta dioica in sprague-dawley rats, Journal of Ethnopharmacology, 55(2) (1997) 107-111.

[54] J. Ancerewicz, E. Migliavacca, P. A. Carrrupt, B. Testa, F. Bree, R. Zini, J. P. Tillement, S. Labidelle, D. Guyot, A. M. Chauvet-Monges, A. Crevat, A. Le Ridant, Structureproperty relationships of trimetazidine derivatives and model compounds as potential antioxidants, Free Radical Biology and Medicine, 25(1) (1998) 113-120.

[55] A. Rohman, S. Riyanto, N. Yuniarti, W.R. Saputra, R. Utami, W. Mulatsih, Antioxidant activity, total phenolic, and total flavaonoid of extracts and fractions of red fruit (Pandanus conoideus Lam), International Food Research Journal, 17(1) (2010) 97-106.

[56] S. Dudonne, X. Vitrac, P. Coutiere, M. Woillez, J. M. Mérillon, Comparative study of antioxidant properties and total phenolic content of 30 plant extracts of industrial interest using DPPH, ABTS, FRAP, SOD, and ORAC assays, Journal of Agricultural and Food Chemistry, 57(5) (2009) 1768-1774.
[57] G. Piluzza, S. Bullitta, Correlations between phenolic content and antioxidant properties in twenty-four plant species of traditional ethnoveterinary use in the Mediterranean area, Pharmaceutical Biology, 49(3) (2011) 240-247.

[58] S. F. Sulaiman, N. A. M. Yusoff, I. M. Eldeen, E. M. Seow, A. A. B. Sajak, K. L. Ooi,. Correlation between total phenolic and mineral contents with antioxidant activity of eight Malaysian bananas (Musa sp.), Journal of Food Composition and Analysis, 24(1) (2011) 1-10.

[59] X. Li, X. Wu, L. Huang, Correlation between antioxidant activities and phenolic contents of radix Angelicae sinensis (Danggui), Molecules, 14(12) (2009) 5349-5361.

[60] Y. Z. Cai, Q. Luo, M. Sun, H. Corke, Antioxidant activity and phenolic compounds of 112 Chinese medicinal plants associated with anticancer, Life Sciences, 74(17) (2004) 2157-2184.

[61] A. Djeridane, M. Yousfi, B. Nadjemi, D. Boutassouna, P. Stocker, N. Vidal, Antioxidant activity of some Algerian medicinal plants extracts containing phenolic compounds, Food Chemistry, 97(4) (2006) 654-660.

[62] A. Vinson, X. Su, L. Zubik, P. Bose, Phenol antioxidant quantity and quality in foods: fruits, Journal of Agricultural and Food Chemistry, 49(11) (2001) 5315-5321.

[63] M. Ogata, M. Hoshi, S. Urano, T. Endo, Antioxidant activity of eugenol and related monomeric and dimeric compounds, Chemical and Pharmaceutical Bulletin, 48(10) (2000) 1467-1469.

[64] İ. Gülçin, Antioxidant activity of eugenol: A structureactivity relationship study, Journal of Medicinal Food, 14(9) (2011) 975-985.

[65] D. P. Bezerra, G. C. G. Militão, M. C. de Morais, D. P. de Sousa, The Dual antioxidant/prooxidant effect of eugenol and its action in cancer development and treatment, Nutrients, 9(12) (2017) 1367.

[66] N. Ito, M. Hirose, S. Fukushima, H. Tsuda, T. Shirai, M. Tatematsu, Studies on antioxidants: their carcinogenic and modifying effects on chemical carcinogenesis, Food and Chemical Toxicology, 24(10-11) (1986) 1071-1082.

[67] A. Kotironta, K. Lounatma, M. Haapasolo, Epidemology and pathogenesis of Bacillus cereus infections, Journal of Microbes and Infection, 2(2) (2000) 189-198.

[68] M. Oussalah, S. Caillet, L. Saucier, M. Lacroix, Inhibitory effects of selected plant essential oils on the growth of four pathogenic bacteria: E. coli 0157:H7, Salmonella Typhimurium, Staphylococcus aureus and Listeria monocytogenes, Food Control, 18(5) (2007) 414-420.

[69] F. A. H. Boyd, N. Benkeblia, In vitro evaluation of antimicrobial activity of crude extracts of Pimenta dioica L.(Merr.), Acta Horticulturae, (1047) (2014) 199-205.

[70] M. B. Lohse, M. Gulati, A. D. Johnson, C. J. Nobile, Development and regulation of single-and multi-species Candida albicans biofilms, Nature Reviews Microbiology, 16(1) (2018) 19-31.

[71] E. L. D. Souza, T. L. M. Stamford, E. D. O. Lima, V. N. Trajano, F. J. M. Barbosa, Antimicrobial effectiveness of spices: An approach for use in food conservation systems, Brazilian Archives of Biology and Technology, 48(4) (2005) 549-558.

[72] N. Ivanovska, S. Philipov, R. Istatkova, P. Georgieva Antimicrobial and immunological activity of ethanol extracts and fractions from Isopyrum thalictroides, Journal of Ethnopharmacology, 54(2-3) (1996) 143-151.

[73] S. S. Rani, N. Saxena, N. Udaysree, Antimicrobial activity 
of black pepper (Piper nigrum L.), Global Journal of Pharmacology, 7(1) (2013) 87-90.

[74] A. Ahmad, A. Khan, L. A. Khan, N. Manzoor, In vitro synergy of eugenol and methyleugenol with fluconazole against clinical Candida isolates, Journal of Medical Microbiology, 59(10) (2010) 1178-1184.

[75] T. N. Kaul, E. Middleton Jr, P. L. Ogra, Antiviral effect of flavonoids on human viruses, Journal of Medical Virology, 15(1) (1985) 71-79.

[76] D. L. Custódio, R. P. Burgo, B. Moriel, A. D. M. Barbosa, M. I. Rezende, J. F. D. S. Daniel, T. D. J. Faria, Antimicrobial activity of essential oils from Pimenta pseudocaryophyllus and Tynanthus micranthus, Brazilian Archives of Biology and Technology, 53(6) (2010) 1363-1369.

[77] S. Burt, Essential oils: their antibacterial properties and potential applications in foods-a review, International Journal of Food Microbiology, 94(3) (2004) 223-253.

[78] M. T. Saenz, M. P. Tornos, A. Alvarez, M. A. Fernandez, M. D. García, Antibacterial activity of essential oils of Pimenta racemosa var. terebinthina and Pimenta racemosa var. grisea, Fitoterapia, 75(6) (2004) 599-602.

[79] M. Martinez-Velazquez, G. A. Castillo-Herrera, R. Rosario-Cruz, J. M. Flores-Fernandez, J. Lopez-Ramirez, R. Hernandez-Gutierrez, E. del Carmen Lugo-Cervantes, Acaricidal effect and chemical composition of essential oils extracted from Cuminum cyminum, Pimenta dioica and Ocimum basilicum against the cattle tick Rhipicephalus (Boophilus) microplus (Acari: Ixodidae), Parasitology Research, 108(2) (2011) 481-487.

\section{Izvod \\ HEMIJSKI SASTAV, ANTIOKSIDATIVNA I ANTIMIKROBNA AKTIVNOST ETARSKOG ULJA I EKSTRAKTA NAJKVIRCA (PIMENTA DIOICA (L.) MERR.)}

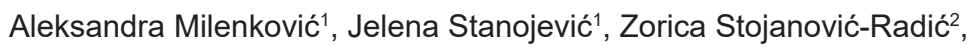

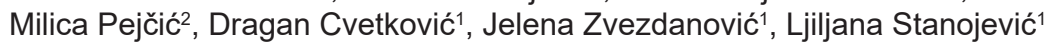

${ }^{1}$ Tehnološki fakultet, Univerzitet u Nišu, Leskovac, Srbija

2Prirodno-matematički fakultet, Univerzitet u Nišu, Niš, Srbija

Plod najkvirca (Pimenta dioica (L.) Merr.) korišćen je za izolaciju etarskog ulja i etanolnog ekstrakta u ovom istraživanju. Etarsko ulje je dobijeno Clevenger hidrodestilacijom iz ploda najkvirca pri hidromodulu $1: 10 \mathrm{~m} / \mathrm{v}$ u toku 180 minuta, dok je etanolni ekstrakt dobijen refluks ekstrakcijom na temperaturi ključanja pri solvomodulu $1: 10 \mathrm{~m} / \mathrm{v}$ u toku 120 minuta. Kvalitativni i kvantitativni sastav dobijenog etarskog ulja određen je GC/MS i GC/FID metodama, respektivno. Sadržaj ukupnih fenola i flavonoida određen je spektrofotometrijski, Folin-Ciocalteu i $\mathrm{AlCl}_{3}$, metodoma, respektivno. Antioksidativna aktivnost etarskog ulja i ekstrakta ploda najkvirca određena je spektrofotometrijski primenom DPPH testa, dok je antimikrobna aktivnost određena mikrodilucionom metodom na sledeće mikroorganizme: dve vrste bakterija (Bacillus cereus, Salmonella spp.) i jedan kvasac (Candida albicans), pri čemu su testirani parovi referentnih sojeva i njihovih izolata. $\mathrm{Na}$ osnovu dobijenih rezultata utvrđeno je prisustvo 20 komponenti u etarskom ulju, uglavnom oksigenovanih monoterpena sa najvišim sadržajem eugenola $(48,5 \%)$ i metil eugenola (35,0\%). Ekstrakt i etarsko ulje su pokazali najbolju antioksidativnu aktivnost posle 20 i 60 minuta inkubacije sa $E_{50}$ vrednostima $0,011 \mathrm{mg} / \mathrm{cm}^{3}$ i $0,023 \mathrm{mg} / \mathrm{cm}^{3}$, respektivno. Etarsko ulje i ekstrakt pokazali su inhibitorno dejstvo na sve ispitivane mikroorganizme. Etanolni ekstrakt najkvirca pokazao je bolji inhibitorni efekat na B. cereus i S. enterica (izolat i ATCC sojeve) od etarskog ulja. Etarsko ulje najkvirca pokazalo je bolji inhibitorni efekat na sojeve C. albicans. Dobijeni rezultati ukazuju na to da su i etarsko ulje i ekstrakt izolovani iz aromatičnog ploda najkvirca dobar izvor prirodnih antioksidanasa i antimikrobnih sredstava sa potencijalnom primenom u prehrambenoj i farmaceutskoj industriji kao sigurnija alternativa sintetičkim aditivima.
(ORIGINALNI NAUČNI RAD) UDK 665.52:582.776.2

Ključne reči: Najkvirc, Etarsko ulje, Ekstrakt, Antioksidativna aktivnost, Antimikrobna aktivnost 